\title{
UNIVERSITYOF
}

FORWARD

THINKING

WESTMINSTER用

WestminsterResearch

http://www.westminster.ac.uk/westminsterresearch

Corporate Governance and Firm Risk

Mathew, S., Ibrahim, S. and Archbold, S.

This article is (c) Emerald and permission has been granted for this version to appear here: http://westminsterresearch.wmin.ac.uk/

Emerald does not grant permission for this article to be further copied/distributed or hosted elsewhere without the express permission from Emerald Group Publishing Limited.

The final, published version in Corporate Governance: The international journal of business in society, 18 (1), pp. 52-67, 2018 is available at:

https://dx.doi.org/10.1108/CG-02-2017-0024

The WestminsterResearch online digital archive at the University of Westminster aims to make the research output of the University available to a wider audience. Copyright and Moral Rights remain with the authors and/or copyright owners.

Whilst further distribution of specific materials from within this archive is forbidden, you may freely distribute the URL of WestminsterResearch: ((http://westminsterresearch.wmin.ac.uk/)).

In case of abuse or copyright appearing without permission e-mail repository@westminster.ac.uk 


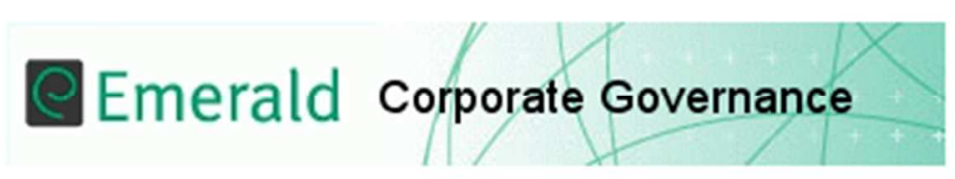

\section{Corporate Governance and Firm Risk}

\begin{tabular}{|r|l|}
\hline Journal: & Corporate Governance \\
\hline Manuscript ID & CG-02-2017-0024.R1 \\
\hline Manuscript Type: & Original Article \\
\hline Keywords: & Board attributes, Governance index, Firm risk, Corporate Governance \\
\hline \multicolumn{2}{|}{} \\
\hline
\end{tabular}

SCHOLARONE ${ }^{\text {M }}$

Manuscripts 


\title{
Corporate Governance and Firm Risk
}

\begin{abstract}
Purpose: This study explores the relationship between the board governance structure and firm risk. Specifically, we develop a 'Governance index' based on four different aspects of the board: 1. Board composition, 2. Board leadership structure, 3. Board member characteristics and 4. Board processes, and examine how the overall index relates to firm risk. Design: The study is conducted using a sample of 268 UK firms from the FTSE 350 index, over the period 2005 to 2010. An index is constructed to capture the overall governance structure of the firm. Regressions of the index on three risk measures are examined. Findings: We find that the governance index that aggregates the four sets of board attributes is significantly negatively related to firm risk. Robustness tests confirm this result.

Research Implications: A large number of studies have explored the relationship between the attributes of corporate boards and firm performance, with mixed results. A much smaller number of studies have looked at board attributes and firm risk, but these have either focused on financial sector firms alone, or have included only a single or a limited number of attributes. This study, utilizing a broad agency framework, seeks to extend the work on firm risk and board attributes, by both expanding industry sectors examined and employing a comprehensive set of board attributes.

Originality: The findings have policy and practical implications for investors, regulators, and chairmen of boards of governors to the extent that they inform these constituencies about the set of board attributes that are associated with firm risk. This study is the first to utilize a comprehensive measure of governance and relate it to firm risk.
\end{abstract}

Keywords: Corporate Governance, Board Attributes, Governance Index, Firm Risk

Paper Type: Research paper

JEL codes: M14; G31; G34 


\section{INTRODUCTION}

The purpose of this study is to utilise a comprehensive set of corporate governance attributes focusing on the board of directors to determine an overall 'Governance Index' representing governance effectiveness; and investigate how this relates to firm risk. The role of corporate governance and risk management has been highlighted following recent regulatory reforms. For example, the Financial Reporting Council (FRC) in the UK, published Boards and Risk (FRC, 2011) outlining the responsibilities of boards of directors for 'risk decision-making', determining 'the company's approach to risk, setting its culture, risk identification, oversight of risk management, and crisis management'. In the US, corporate governance reforms which form part of the Sarbanes-Oxley Act (2002) provide specific guidance on internal control mechanisms and board attributes to improve corporate accountability and reduce the risk of firm insolvency.

Prior research on governance indices typically measure areas such as shareholder rights (Gompers et al., 2003; Brown and Caylor, 2006; Bebchuk et al., 2009), ownership and leadership structures (Anlin et al., 2007), or the severity of agency conflicts (Renders and Gaeremynck, 2012). Following Zahra and Pearce (1989), we focus on the internal structure of governance and group board attributes into four factors: 1. Board composition, 2. Board leadership structure, 3. Board member characteristics and 4. Board processes. We construct a Governance Index based on the above attributes and examine its relationship with different measures of firm risk. The governance index can potentially indicate to investors the boards that are more risk-seeking or risk-averse based on their composition, leadership structure, characteristics and the processes they follow. This index differs from those in prior studies given that the former tend to focus on external and stakeholder factors and not so 
much on internal board attributes. Furthermore, no prior studies have examined an overall index based on the board attributes of governance in relation to firm risk.

Prior empirical literature on the composition of boards and the attributes of board members has tended to focus on the relationship between these factors and firm performance (Dalton et al., 1998; Bhagat and Black, 2002; Van der Walt et al., 2006; Bhagat and Bolton, 2008; Brown and Caylor, 2009; Adams et al., 2010; Bozec et al., 2010; Mangena et al., 2012; Bhagat and Bolton, 2013; Upadhyay et al., 2014) or other dimensions such as firm innovation (Zona et al., 2013); or they focus on the factors that make boards effective (Minichilli et al., 2009; Ben-Amar et al., 2013). However, limited prior research shows that certain attributes of corporate governance are linked to the variability in performance, or firm risk. These studies are typically based on US samples in the financial sector (Pathan, 2009; Llewellyn and Muller-Kahle, 2012) and/or involve only a limited set of board attributes such as board size, independence, CEO power and board equity ownership (Brick and Chidambaran, 2008; Cheng, 2008; Delgado-García et al., 2010; Geppert et al., 2013) rather than an overall governance index.

Using a sample of 267 non-financial firms, drawn from the FTSE 350 index over the years 2005 to 2010, we find that the Governance index is significantly associated with measures of firm risk. Specifically, we find that a larger value of the Governance Index is associated with lower firm risk. The Governance index is composed of four attributes: 1. Board Composition, which consists of variables relating to board size, the proportion of nonexecutive directors and gender diversity, 2. Board Leadership Structure which indicates the power of the chief executive officer (hereafter, CEO) and executives' equity ownership, 3. Board Characteristics which includes the average age and tenure of board members, and 4. 
Board Process which includes variables related to percentage of board attendance and frequency of audit meetings.

We contribute to the corporate governance literature in two ways. First, we examine how a comprehensive set of board attributes are associated with firm risk; the lack of studies in the literature that examine this relationship is significant because firms' long-term shareholders are not only concerned with the size and growth in their investment, but also the volatility in the returns, which is a measure of firm risk (Luo and Bhattacharya, 2009). Second, we measure an overall board index or Governance Index, which represents the internal structure and process of the board of directors, rather than external factors related to governance or how the board interacts with stakeholders. This index can be used by shareholders and other stakeholders to gauge the level of risk-taking in firms based on the governance structure.

The remainder of the paper is organized as follows. The next section presents the theoretical context for our study and reviews the empirical literature on board attributes and governance indices from which we develop the hypothesis to be tested. In section three, we outline the methodology employed and present the development of the Governance index, along with the sample selection. In section four, we present and discuss the empirical findings and robustness tests, followed by concluding remarks in the final section.

\section{LITERATURE REVIEW AND HYPOTHESIS DEVELOPMENT}

\subsection{Board attributes and risk}

Prior empirical studies that have examined the relationship between board attributes and firm risk typically examine only a limited number of board attributes. For example, Pathan (2009) finds, in a sample of 212 US banks over 1997-2004 that firm risk 
is negatively associated with board size, the number of independent directors and CEO power but is positively associated with CEO equity ownership. Cheng (2008) also finds, in a US sample over the period 1996-2004, that board size is negatively associated with variability of firm performance, or firm risk. Platt and Platt (2012) examine several board attributes in relation to insolvency and find that bankrupt firms have less independent directors, smaller board sizes, higher equity ownership by directors, and smaller audit, compensation and nomination committees. This implies that these factors are related to firm risk. Mathew et al. (2015) find a significant relationship between firm risk and board size, as well as executive and institutional ownership using a UK-based sample.

Other studies that study board attributes in relation to firm risk include those that examine board independence which find this to be negatively related to firm risk (Brick and Chidambaran, 2008; Djerbi and Anis, 2015) and CEO power which is positively related to firm risk (Adams et al., 2005; Llewellyn and Muller-Kahle, 2012; Djerbi and Anis, 2015). Furthermore board ownership is found to be related to firm risk (Saunders et al., 1990); specifically, family ownership vs. diversified ownership leads to different risk profiles and managerial risk-taking in the context of international acquisitions (Geppert et al., 2013). Harjoto et al. (2014) also find that boards with diversity in terms of gender, race, age, experience, tenure and expertise are more risk averse. Callen and Fang (2013) find that transient institutional investor ownership increases firm risk. Gender diversity in top management levels is also associated with lower firm risk (Perryman et al., 2016). Sun and Liu (2014) ascertain that banks with long board tenure audit committees have lower total and idiosyncratic risk. Furthermore, Bennett (2013) confirm that increased monitoring, through increased board attendance as well as other factors, is associated with less risk-taking. Therefore, empirical evidence shows that specific board attributes are associated with firm 
risk. However, governance attributes do not exist in isolation and the combination of these attributes can lead to different risk-taking behaviour. The following section discusses prior empirical research that has developed indices to capture overall governance structures.

\subsection{Governance indices}

Prior research that has examined a combination of board attributes typically forms an index that represents board effectiveness. Some well-known indices such as the Governance Risk indicator (GRId) formulated by Institutional Shareholders Services Inc. combine variables representing board composition and independence, compensation, ownership, audit process and shareholder rights/takeover defences (ISS, 2012). However, many of the indices used in prior research measure only external factors such as shareholder rights. For example, Gompers et al. (2003) use the incidence of twenty four governance rules to construct a governance index to proxy for the level of shareholder rights. They find that firms with stronger shareholder rights have higher firm value, higher profits, higher sales growth, lower capital expenditures, and make fewer corporate acquisitions. Bebchuk et al. (2009) provide an entrenchment index based on six shareholder rights provisions and find that this index is associated with firm value.

Other research measuring an overall governance index include Brown and Caylor (2006), who examine a set of 51 firm-specific provisions representing both internal and external governance and test how these relate to firm valuation. They include shareholder rights factors (e.g. whether the board is staggered and if there are poison pill agreements) as well as some internal factors (e.g. independence of board members and attendance at board meetings). Anlin et al. (2007) provide an index representing ownership and leadership structures and examine how this relates to share price in Taiwanese firms. The index includes factors related to: CEO duality, size of the board of directors, management's holdings and block 
shareholders' holdings. They find that the index can proxy for effective governance and is associated with firm value. Renders and Gaeremynck (2012) construct a measure of the severity of the principal-principal conflict which includes variables that increase majority shareholders' ability to extract private benefits. They use the index to measure governance effectiveness and relate to firm value. Therefore, prior studies presenting governance indices tend to focus on external and stakeholder factors and focus on how the index relates to firm value and performance.

\subsection{Hypothesis development}

In terms of overall governance factors that relate to firm risk, it is likely that internal factors related to the board will be more relevant. According to agency theory, the separation of ownership and control has the potential to create agency problems, which can result in agents employing strategies to promote their self-interest to the detriment of principals (Jensen and Meckling, 1976; Fama and Jensen, 1983). Therefore, boards of directors are needed to monitor the firm's activities in the interest of stakeholders including shareholders, creditors, employees and society (Mallin, 2013). Utilising an agency perspective, Zahra and Pearce (1989) propose four attributes of the board, namely composition, structure, characteristics and process that influence how boards carry out their roles as seen in Figure 1. These attributes represent a mix of attributes specific to board members as well as the overall functioning of the board. Board composition refers to the size of the board and the mix of board members e.g. in terms of independence. Board structure refers to board organization and division of labor among committees. Board characteristics refer to directors' experience and factors that influence the performance of their tasks. Finally, board process refers to the decision-making related activities (Zahra and Pearce, 1989, p. 292). The mix of attributes therefore determines how the board carries out the roles of control, service and strategy which influence strategic outcomes and hence firm performance (Zahra and Pearce, 1989). It 
is expected that the board attributes will be related to firm risk through their impact on the strategic direction of management and control function.

(Figure 1)

Based on the categories of board attributes discussed in Zahra and Pearce (1989), namely board composition, leadership structure, board characteristics and board processes, it is expected that a single Governance Index that forms a measure of the overall governance environment and monitoring effectiveness based on these attributes will be related to firm risk. Therefore, our hypothesis is as follows:

$\boldsymbol{H}_{a}:$ A governance index which consists of board composition, leadership structure, board characteristics and board process is related to firm risk.

\section{SAMPLE SELECTION AND METHODOLOGY}

The sample in this study is comprised of firms in the UK-based FTSE 350 index over the period 2005-2010. The time period is selected to follow the adoption of International Financial Reporting Standards (IFRS) in 2005. We exclude utility and financial firms due to their different regulatory environment and include all firms that were on the index for at least two consecutive years to reduce survivorship bias. This results in an unbalanced sample of 267 firms over the period or 1,410 observations. Financial data was collected from the Bloomberg database and data on the board members was hand collected from the Morningstar database. Table 1 shows the distribution of the sample by industry and year. As can be seen from the table, the sample ranges from 228 to 242 firm-observations per year. The majority of the observations are from the industrials and consumer service industries $(\mathrm{N}=420+413=833)$. The next largest industry in terms of sample observations is consumer goods $(\mathrm{N}=190)$ followed by basic materials $(\mathrm{N}=106)$ and oil and gas $(104)$. The industrial 
distribution across years is consistent.

\section{(Table 1)}

To analyse the relationship between board attributes and firm risk, we use the following linear regression model based on Adams et al. (2005), Cheng (2008) and Pathan (2009):

$\operatorname{Ln}\left(\right.$ Risk $\left._{i t}\right)=\alpha_{0}+\alpha_{1}$ Governance Index $_{i t}+\alpha_{2}$ Leverage $_{i t}+\alpha_{3}$ Firm Size $_{i t}+\alpha_{4}$ Growth $_{i t}+\alpha_{4}$

Performance $_{i t-1}+\sum_{j=1-8} \alpha_{j}\left({\left.\text { Industry } \text { Dummies }_{i t}\right)}\right)+\sum_{t=1-6} \alpha_{t}\left(\right.$ Year Dummies $\left._{i t}\right)+\varepsilon_{i t}$

Where

Risk $\quad$ Firm risk for firm i in year $\mathrm{t}$ measured as either Total Risk, Asset Return Risk or Idiosyncratic Risk, as described in the next section;

Governance the Governance Index for firm i in year $\mathrm{t}$, as described in the next section;

Index $_{\text {it }}$

Leverage $_{i t} \quad$ Average total assets of firm i in year t over average total common equity;

Firm Size $_{i t} \quad$ Market capitalization of firm $\mathrm{i}$ in year $\mathrm{t}$ measured as total value of issued shares;

Growth $_{i t} \quad$ Capital expenditures of firm i in year t over sales;

Performance $_{i t-1}$ Return on assets for firm $\mathrm{i}$ in year $\mathrm{t}-1$ measured as net income over total assets;

$\varepsilon_{i t} \quad$ The residual.

We use Generalised Least Squares random effects method to estimate the model since board attributes which are time invariant cannot be estimated with fixed effect regressions. We include several control variables that may impact the level of firm risk in the above regression. Firstly, we include Leverage since high financial leverage is associated with less firm risk due 
to the burden of repayment (Cheng, 2008). We also include Firm Size as large firms may have more natural hedges against economic fluctuations, better access to capital markets and can borrow on better terms (Ferri and Jones, 1979). We also include Growth as firms that have more growth opportunities will take this opportunity to expand and take on new projects which might impact firm risk. Lagged Performance is included since firms can change risk taken in a particular year through investment choices depending on the previous performance of the firm (Cheng, 2008). Finally, we include industry and year dummies as control variables.

\subsection{Measures of risk}

Three alternative measures of firm risk are employed based on Laeven and Levine (2009) and Pathan (2009). Specifically, we use Total Risk, Asset Return Risk and Idiosyncratic Risk as defined below (firm and year subscripts have been excluded for simplicity):

Total Risk Standard deviation of annualised daily stock returns measured as the natural logarithm of the ratio of equity return series;

Asset Return Risk Ratio of market value of equity to market value of total assets times the standard deviation of annualised daily stock returns for a firm $* \sqrt{ } 250$;

Idiosyncratic Risk Risk specific to the firm downloaded from Bloomberg database.

The first measure, Total Risk, uses market data and includes both the risk involved in the particular stock (idiosyncratic risk) and market risk (systematic risk). This reflects the market's perception about the risks inherent in the firm's assets and liabilities. Both regulators and firm executives frequently monitor this risk (Pathan, 2009).

Asset Return Risk is used as an alternative risk measure which represents the variance of 
asset returns. Following Flannery and Rangan (2008) and Pathan (2009), volatility of asset returns is computed as the ratio of market value of equity to market value of total assets multiplied by the standard deviation of the daily stock returns and annualised by multiplying the resulting value by the square root of the approximate number of trading days in the year which is 250 .

Idiosyncratic Risk represents risk specific to the firm which is unrelated to the market and cannot be diversified away. This data was obtained from the Bloomberg database.

\subsection{Construction of Governance Index}

The Governance Index is a proxy for governance effectiveness and focuses on the internal mechanism and attributes of the board of directors. It is composed of factors related to: 1 . Board composition, 2. Board leadership structure, 3. Board characteristics and 4. Board processes. The specific variables included for each board attribute is guided by prior empirical research as included in the literature review. All variables included in the index are constructed by using indicator variables taking the value of 1 when the value of the variable is either above or below the median. In our choice of the direction of the indicator variables, we rely on prior research in determining whether the variable is expected to be positively or negatively related to firm risk. ${ }^{1}$ We therefore propose a proxy which we expect to measure board effectiveness in terms of risk behavior; specifically, we expect this proxy to be negatively related to firm risk.

Our first attribute, Board Composition is composed of board size, the proportion of non-

\footnotetext{
${ }^{1}$ In untabulated results, we also regress firm risk on each board attribute separately to confirm the direction of the association.
} 
executive directors (NEDs) and the percentage of women on the board. As shown in the literature a large board size, a higher percentage of NEDs and higher percentage of women on the board is related to low firm risk (e.g. Pathan, 2009; Harjoto et al., 2014) and better monitoring (Adams and Ferreira, 2009). Therefore board size that is equal and larger than the median value in the sample is assigned the value 1 , otherwise it takes the value 0 (I-Board Size). Similarly, the percentage of NEDs and percentage of women on the board that have a value equal to or greater than the median take the value of 1 (indicative of low risk), otherwise they take the value 0 (I-Percentage of NEDs and I-Percentage of Women).

The second factor, Board Leadership Structure, consists of three variables - Powerful CEO, Board executive ownership and Block ownership. The first variable, I-Powerful CEO takes the value 0 if the CEO is also the chairperson, the chairperson is an executive, or the CEO is a founder of the firm, and 1 otherwise; given that powerful CEOs are positively related to risk (e.g. Adams et al., 2005). The second variable I-Board Executive Ownership takes the value 0 when board ownership is greater than the median value and 1 otherwise. This is in line with prior research that finds that board ownership is positively related to firm risk (Pathan, 2009) and negatively related to earnings quality in line with the management entrenchment theory (Pergola and Joseph, 2011). Lastly, I-Block Ownership takes the value 0 when percentage of equity owned by institutional investors is greater than the median value and 1 otherwise, given that there is a positive relationship between institutional investor ownership and firm risk (Callen and Fang, 2013).

The third attribute, Board Characteristics, consists of variables related to board member age and tenure. The first variable, I-Board Age is created which takes the value 1 when board age is greater than the median, 0 otherwise. Also I-Board Tenure takes the value 1 when board tenure is greater than the median and 0 otherwise given that higher age and 
tenure are linked with lower firm risk (Harjoto et al., 2014, Sun and Liu, 2014).

The final attribute, Board Process, consists of the variables related to board meetings attendance and frequency of audit committee meetings. I-Board Attendance takes the value 1 when board attendance of the board members is greater than the median, 0 otherwise. Also I-Frequency of Audit Meetings takes the value 1 when total number of audit committee meetings is greater than the median, 0 otherwise. Since board meetings are found to be negatively related to firm risk (Bennett, 2013), these variables are constructed in this way.

The overall measure of governance related to board attributes, the Governance Index, is constructed by combining all the variables described above in the four categories. The index can range from 0 to 10 given that it includes 10 indicator variables taking on the value 0 or 1 .

Governance Index = I-Board Size + I-Proportion of NEDs + I-Percentage of Women + IPowerful CEO + I-Board Equity Ownership + I-Block Ownership + I-Board Age + IBoard Tenure + I-Board Attendance + I-Frequency of Audit Meetings

\section{DESCRIPTIVE STATISTICS AND RESULTS}

\subsection{Descriptive statistics}

We begin by presenting descriptive statistics for all board variables as well as the index, dependent and control variables in Table 2. The results show that the mean board size of the sample is 8.95 ranging from a minimum of 5 to a maximum of 19 ; the mean percentage of NEDs is $62 \%$ and the percentage of women on boards is about $8 \%$. Furthermore, the percentage of firms with a powerful CEO is $18 \%$ and the mean value of board ownership is $4 \%$, ranging from $0 \%$ to $72 \%$. The mean percentage of block ownership held by institutional investors is $34 \%$, while the mean tenure of the board is about 5 years 
and mean age of the board members is about 56 years. Average board attendance is $95 \%$ per year while the mean frequency of audit meetings is 4 times per year.

\section{(Table 2)}

In terms of the descriptive statistics of the board index, we find that the Governance index ranges from 0 to 9 with a mean of 4.34 and standard deviation of 1.75 .

In terms of the risk variables, the mean value for Total Risk is 0.4 with a standard deviation of 0.2. Asset return risk had a mean of 0.39 and standard deviation of 0.19 while Idiosyncratic Risk has a mean of -0.57 and standard deviation of 0.50 .

In terms of the control variables, Leverage has a mean of 5.01 with a standard deviation of 39.69 which shows that the variation in leverage across the sample is high. The smallest Firm Size is $£ 10$ million and the largest of $£ 138$ billion while Growth has a minimum value of 0.02 and a maximum of 1,555. Finally, Lagged Performance has a mean of 7.57 and ranges from 175.74 to 175.92 .

Table 3 presents the Pearson correlation coefficients between the board variables, with significant correlations (at the $10 \%$ level or less) shown in bold. The highest correlation is between Firm Size and Board Size which is 0.48; all other correlations are below this value. Therefore, multicollinearity between the independent variables is not of concern. The Percentage of NEDs is negatively correlated to the presence of a Powerful $C E O,(\beta=-0.42$, $\mathrm{p}<0.05$ ) indicating that powerful CEOs may want less challenge by having more NEDs on board.

(Table 3) 
The Frequency of Audit Meetings and Firm size are positively correlated $(\beta=0.41, p<.05)$, showing that larger firms require more attention from the audit committee and for such firms the board size is also large. Powerful CEO is also positively and significantly correlated with Board Ownership with a value of 0.33 .

The correlation between the dependent variables and the explanatory variables are also presented and even though many coefficients are significant, no correlation coefficient exceeds the value of 0.2 .

\subsection{Main Results}

Table 4 shows the results using the Governance index as the independent variable with all three risk measures. The results in the table show that the Governance index is significantly and negatively related to Total Risk $(\beta=-0.020, \mathrm{p}<.001)$, Asset Return Risk $(\beta=-0.019, \mathrm{p}<.001)$ and Idiosyncratic Risk $(\beta=-0.037, \mathrm{p}<.001)$.

As discussed above, the Governance Index is a sum of indicator variables related to the aforementioned governance attributes and can vary from 0 to 9 . The results show that an increase in the Governance Index by 1 unit reduces total firm risk by $2 \%$, which is a decrease in its stock price volatility. To further investigate the impact of changes in the governance attributes on the Governance Index, we consider some firms where the index has increased/decreased by one unit. For example, BT Group PLC, in the telecommunications sector, had a Governance Index of 3 in year 2007 and 4 in 2008. Examination of the reasons behind this change shows that it was due to an increase in the percentage of NEDs on the board from $62 \%$ to $67 \%$. Furthermore, the index increased from 4 to 5 between 2008 and 2009. This was due to an increase in the audit committee meetings from 4 to 5 over that period. Another example is Electrocomponents PLC, from the technology sector. The 
Governance Index for this firm decreased from 5 to 4 between 2008 and 2009. This was due to a decrease in the average age of the board of director members from 57 to 54 due to the retirement of a board member. Therefore, small changes by firms can result in a one-unit change in the index and therefore a significant reduction in firm risk.

The findings above indicate that lower firm risk is associated with a higher value of the governance index which on average represents firms with large boards, more NEDs and more women on the board; firms that have a leadership structure that does not have a powerful CEO, the equity held by executive board members is not large and equity held by institutional investors is not large. Also, the boards with lower risk have members who are older and have longer tenure with the firm. Moreover, they have more audit committee meetings and better board meeting attendance. Specifically, a unit increase in Governance index is associated with a $2 \%$ lower Total Risk.

The Governance index can be used by shareholders and regulators to identify firms that have boards with lower firm risk. We make no assumptions regarding the relationship between the level of risk and current or future performance. However, untabulated results show that there is a negative relationship between risk in the current year and future performance.

\section{(Table 4)}

In terms of the results for the control variables, we find that larger firms are associated significantly with less risk, particularly Total Risk. On the other hand, firms with higher growth opportunities are associated with greater firm risk across all risk measures. Firms with higher financial leverage also have lower risk. Finally, the previous performance of the firm is found to be inversely related to firm risk, implying that if the previous 
performance of the firm is poor, managers take on more risk in the current period.

\subsection{Robustness Tests:}

In an empirical model, when the dependent variable predicts independent variables, then there is reverse causality. In the presence of reverse causality, estimations produce biased results. Therefore to check for the extent to which endogeneity (due to reverse causality) is a problem, the following test is conducted.

To confirm that causation runs from board index to firm risk, the explanatory variables on the right hand side of empirical model are replaced by their lagged values. The equations are reestimated using generalised least squares with lagged explanatory variables and dependent variable of total firm risk. This test to check for reverse causality has been previously used by Pathan (2009) in his study of how board composition relates to bank risk. The argument for using lagged independent variables is that current values may be endogenous but it is unlikely that past values are subject to the same problem. The results for the Governance index with lagged explanatory variables are shown in Table 5. The results show that the estimations are similar to the estimation using contemporaneous independent variables. The significance of the relationship is similar to the estimates using current independent variables and the direction of the relationship is the same. This shows that endogeneity is not a cause for concern in the empirical model used in this study.

\section{(Table 5)}

Additional analysis using Instrumental variable estimation was conducted as a robustness test to address the endogeneity concern (using xtivreg in STATA). The instruments used were the board attributes that form the board governance index. The results (as shown in Table 6) are similar to the results using the random effects methodology. Specifically, the Governance 
index coefficient is $-0.020,-0.019$ and -0.036 (all significant at the $1 \%$ level) using Total Risk, Asset Return Risk, and Idiosyncratic Risk as dependent variables. This indicates that endogeneity is not a cause for concern in the model used for the study.

\section{(Table 6)}

\section{CONCLUDING REMARKS}

Using a sample of 267 FTSE 350 UK firms between the years 2005 to 2010, our results show that a Governance index constructed from the composition, leadership structure, members' characteristics and board process is negatively related to firm risk. This finding is important for shareholders, regulators, and academicians as it identifies the factors that are significantly related to firm risk. Specifically, boards that are associated with lower firm risk have larger values of the Governance index which on average indicates they are larger boards, have more NEDs and more women on the board; these boards also have a leadership structure that does not have a powerful CEO and the equity held by executive board members as well as institutional investors is not large. Also, the board members are older and have longer tenures with the firm. Moreover, these boards have more audit committee meetings and better board meeting attendance.

As a robustness check, we check for endogeneity of the independent variables by estimating lagged independent variables with firm risk and find that there is no concern regarding endogeneity issues. We also find the same results when using the instrumental variable method.

The policy implications of the findings come from the identification of the board attributes that represent the effectiveness of the board which are associated with firm risk. The use of a Governance index can inform regulators of which firms have effective boards in relation to 
firm risk. Furthermore, the current study is significant in that it examines firm risk and governance attributes in a longitudinal, cross-sectional study. Previous studies focus on the financial sector, especially following the financial crisis of 2007/8 (e.g. Pathan, 2009; Llewellyn and Muller-Kahle, 2012). Therefore, we document that findings in previous research in the financial sector apply to other sectors as well.

As with all research, this study has limitations. One potential limitation is the generalizability of the results. Since this study covers only UK firms, it is possible that the findings would not hold in different regulatory markets. Furthermore, the sample of firms consists of large firms in the UK market and therefore the results may not hold for smaller firms. Finally, the Governance index, while it is comprehensive and includes several governance attributes, does exclude some attributes such as board member experience, qualifications, and expertise. Although these are captured in some of the attributes used such as age and tenure, it may be useful to include them in a governance measure. 


\section{REFERENCES}

Adams, R.B., Almeida, H. and Ferreira, D. (2005), "Powerful CEO's and their impact on corporate performance", The Review of Financial Studies, Vol. 18 No. 4, pp. 1403-1432.

Adams, R.B. and Ferreira, D. (2009), "Women in the boardroom and their impact on governance and performance", Journal of Financial Economics, Vol. 94 No. 2, pp. 291-309.

Adams, R. B., Hermalin, B. and Weisbach, M. S. (2010), "The role of boards of directors in corporate governance: A conceptual framework and survey", Journal of Economic Literature, Vol. 48 No. 1, pp. 58-107.

Anlin, C., Lanfeng, K., Meilan, T. and Ferrell, A. (2007), "Building a corporate governance index from the perspectives of ownership and leadership for firms in Taiwan”, Corporate Governance: An International Review, Vol. 15 No. 2, pp. 251-261.

Bebchuk, L., Cohen, A. and Ferrell, A. (2009), "What matters in corporate governance?", Review of Financial Studies, Vol. 22 No. 2, pp. 783-827.

Ben-Amar, W., Francoeur, C., Hafsi, T. and Labelle, R. (2013), "What makes better boards? A closer look at diversity and ownership", British Journal of Management, Vol. 24 No. 1, pp. 85-101.

Bennett, B. (2013), "Evidence on the value of director monitoring: A natural experiment", Working paper, Arizona State University, available at SSRN: http://ssrn.com/abstract=2218773.

Bhagat, S. and Black, B. (2002), "The non-correlation between board independence and longterm firm performance", Journal of Corporation Law, Vol. 27, pp. 231-274.

Bhagat, S. and Bolton, B. (2008), "Corporate governance and firm performance", Journal of Corporate Finance, Vol. 14, pp. 257-273.

Bhagat, S., and Bolton, B. (2013), "Director ownership, governance and performance", Journal of Financial and Qualitative Analysis, Vol. 48 No. 1, pp. 105-135.

Bozec, R., Dia, M., and Bozec, Y. (2010), "Governance-performance relationship: A reexamination using technical efficiency measures", British Journal of Management, Vol. 21 No.3, pp. 684-700.

Brick, I. E. and Chidambaran, N. K. (2008), "Board monitoring, firm risk, and external regulation", Journal of Regulatory Economics, Vol. 33 No. 1, pp. 87-116.

Brown, L.D. and Caylor, M.L. (2006), "Corporate governance and firm valuation", Journal of Accounting and Public Policy, Vol. 25 No. 4, pp. 409-434.

Brown, L. and Caylor, M. (2009), "Corporate governance and firm operating performance", Review of Quantitative Finance and Accounting, Vol. 32, pp. 129-144 . 
Callen, J.L. and Fang, X. (2013), "Institutional investor stability and crash risk: Monitoring versus short-termism?”, Journal of Banking and Finance, Vol. 37 No. 8, pp. 3047-3063.

Cheng, S. (2008), "Board size and the variability of corporate performance", Journal of Financial Economics, Vol. 87, pp. 157-176.

Dalton, D. R., Daily, C. M., Ellstrand, A. E. and Johnson, J. L. (1998), "Meta-analytic reviews of board composition, leadership structure, and financial performance", Strategic Management Journal, Vol. 19 No. 3, pp. 269-290.

Delgado-García, J. B., De La Fuente-Sabaté, J. M. and De Quevedo-Puente, E. (2010), “Too negative to take risks? The effect of the CEO's emotional traits on firm risk", British Journal of Management, Vol. 21 No. 2, pp. 313-326.

Djerbi, C. and Anis, J. (2015), "Boards, retained ownership and failure risk of French IPO firms", Corporate Governance: The International Journal of Business in Society, Vol. 15 No. 1, pp. 108-121.

Fama, E. F. and Jensen, M. C. (1983), "Separation of ownership and control”, Journal of Law and Economics, Vol. 26 No. 2, pp. 301-326.

Ferri, M. and Jones, W. (1979), "Determinants of financial structure: a new methodological approach" Journal of Finance, 34: pp. 631-644.

FRC (Financial Reporting Council), (2011), "Boards and risk”, available at http://www.frc.org.uk/images/uploaded/documents/Boards\%20and\%20Risk\%20final.pdf (accessed 20 November 2015).

Flannery, M. and Rangan, K. (2008), "What caused the bank capital build-up of the 1990s?”, Review of Finance, Vol. 12 No. 2, pp. 391-429.

Geppert, M., Dörrenbächer, C., Gammelgaard, J., and Taplin, I. (2013), "Managerial risktaking in international acquisitions in the brewery industry: Institutional and ownership influences compared”, British Journal of Management, Vol. 24 No. 3, pp. 316-332.

Gompers, P. A., Ishii J. L. and Metrick A. (2003), "Corporate governance and equity prices”, Quarterly Journal of Economics, Vol. 118 No. 1, pp. 107-155.

Greene, W. H. (2011), Econometric Analysis, 7th edition, Prentice Hall, New Jersey.

Harjoto, M. A., Laksmana, I. and Yang, Y. (2014), "Board diversity and corporate risk taking", Working Paper, Wake Forest University.

ISS (2012), Governance Risk Indicator 2.0, Technical Document, available at http://www.issgovernance.com/files/GRId2.0_TechnicalDocument20120306.pdf (accessed 15 Oct 2015). 
Jensen, M. and Meckling W. (1976), “Theory of the firm: Managerial behaviour, agency costs, and ownership structure", Journal of Financial Economics, V o1. 3, pp. 305-360.

Laeven, L. and Levine, R. (2009), "Bank governance, regulation and risk taking", Journal of Financial Economics, Vol. 93 No. 2, pp. 259-275.

Llewellyn, K.B. and Muller-Kahle, M.I. (2012), “CEO power and risk-taking: Evidence from the subprime lending industry", Corporate Governance: An International Review, Vol. 20 No. 3, pp. 289-307.

Luo, X. and Battacharya, C. (2009), "The debate over doing good: Corporate social performance, strategic marketing levers and firm idiosyncratic risk", Journal of Marketing, Vol. 73 No. 6, pp. 198-213.

Mallin, C. (2013), Corporate Governance, Fourth Edition, Oxford University Press, Oxford, UK.

Mangena, M., Tauringana, V. and Chamisa, E. (2012), "Corporate boards, ownership structure and firm performance in an environment of severe political and economic crisis", British Journal of Management, Vol. 23 No. S1, pp. S23-S41.

Mathew, S., Ibrahim, S. and Archbold, S. (2016) "Boards attributes that increase firm risk evidence from the UK", Corporate Governance: The International Journal of Business in Society, Vol. 16, No. 2, pp. 233-258.

Minichilli, A., Zattoni, A. and Zona, F. (2009), "Making boards effective: an empirical examination of board task performance", British Journal of Management, Vol. 20 No. 1, pp. $55-74$.

Pathan, S. (2009), "Strong boards, CEO power and bank risk-taking", Journal of Banking and Finance, Vol. 33 No. 7, pp. 1346-1350.

Pergola, T.M. and Joseph, G.W. (2011) "Corporate governance and board equity ownership", Corporate Governance: The International Journal of Business in Society, Vol. 11 No. 2, pp. 200-213.

Perryman, A.A., Fernando, G.D. and Tripathy, A. (2016), "Do gender differences persist? An examination of gender diversity on firm performance, risk, and executive compensation", Journal of Business Research, Vol. 69 No. 2, pp. 579-586.

Platt, H. and Platt, M. (2012), "Corporate board attributes and bankruptcy", Journal of Business Research, Vol. 65 No. 8, pp. 1139-1143.

Renders, A. and Gaeremynck, A. (2012), "Corporate governance, principal-principal agency conflicts and firm value in European listed companies", Corporate Governance: An International Review, Vol. 20 No. 2, pp. 125-143.

Sarbanes-Oxley Act, (2002), "Sarbanes-Oxley Act” available at http://www.soxlaw.com/ 
(accessed on 10/10/2012).

Saunders A., Strock E. and Travlos N.G. (1990), “Ownership structure, deregulation, and bank risk taking”, Journal of Finance, Vol. 45 No. 2, pp. 643-654.

Sun, J. and Liu, G. (2014), “Audit committees' oversight of bank risk-taking”, Journal of Banking and Finance, Vol. 40, pp. 376-386.

Upadhyay, A.D., Bhargava, R. and Faircloth, S.D. (2014), "Board structure and role of monitoring committees", Journal of Business Research, Vol. 67 No. 7, pp. 1486-1492.

Van der Walt, N., Ingley, C., Shergill, G. S., and Townsend, A. (2006), "Board configuration: Are diverse boards better boards?" Corporate Governance: The International Journal of Business in Society, Vol.6 No. 2, pp. 129-147.

Zahra, S. A. and Pearce II, J. A. (1989), "Boards of directors and corporate financial performance: A review and integrative model", Journal of Management, Vol. 15 No. 2, pp. 291.

Zona, F., Zattoni, A. and Minichilli, A. (2013), "A contingency model of boards of directors and firm innovation: the moderating role of firm size", British Journal of Management, Vol. 24 No. 3, pp. 299-315. 
Appendix - Definition and Measurement of variables

\begin{tabular}{ll}
\hline Variables & The number of directors on the firm's board \\
\hline Board size & The percentage of non-executive independent board directors \\
Percentage of women & Percentage of women on the board \\
Powerful CEO & $\begin{array}{l}\text { Dummy variable which takes the value } 1 \text { if there duality of CEO-chairman } \\
\text { position, CEO is founder or Chairman is an executive. }\end{array}$ \\
Board executive ownership & $\begin{array}{l}\text { Equity ownership of all the executive board members as a percentage of the } \\
\text { outstanding shares }\end{array}$ \\
Block ownership & $\begin{array}{l}\text { Percentage of total of substantial institutional investors holding more than } 3 \% \\
\text { of shares in the firm }\end{array}$ \\
Board Age & Average age of the board members in the firm \\
Board Tenure & Average tenure of the board members in the firm in years \\
Board meeting attendance & Average board attendance of the board members \\
Audit Committee meeting & The total number of audit committee meeting during the year
\end{tabular}

Index Variables

Board Composition

I-Board Size

I-Percentage of NEDs

I-Percentage of Women

Board Leadership Structure

I-Powerful CEO

I-Board Executive Ownership

I-Block Ownership

Board Characteristics

I-Board Age

I-Board Tenure

Board Process

I-Board Attendance

I-Frequency of Audit Meetings

Governance index

\section{Risk Measures}

Total risk

Asset Return risk

Idiosyncratic risk

Indicator variable that takes the value 1 when board size is greater than the median value, 0 otherwise

Indicator variable that takes the value 1 when proportion of NEDs is greater than the median value, 0 otherwise

Indicator variable that takes the value 1 when percentage of women is greater than the median value, 0 otherwise

Indicator variable that takes the value 0 if the $\mathrm{CEO}$ is also the chairperson, the chairperson is an executive, or the CEO is a founder of the firm, and 1 otherwise Indicator variable that takes the value 0 when board ownership is greater than the median value, 1 otherwise

Indicator variable that takes the value 0 when percentage of equity owned by institutional investors is greater than the median value, 1 otherwise

Indicator variable that takes the value 1 when board age is greater than the median value, 0 otherwise

Indicator variable that takes the value 1 when board tenure is greater than the median value, 0 otherwise

Indicator variable that takes the value 1 when average board attendance of the board members is greater than the median value, 0

Indicator variable that takes the value 1 when total number of audit committee meeting is greater than the median value, 0 otherwise

I-Board Size + I-Proportion of NEDs + I-Percentage of Women + I-Powerful CEO + I-Board Executive Ownership + I-Block Ownership + I-Board Age + I-Board Tenure + I-Board Attendance + I-Frequency of Audit Meetings

Standard deviation of the daily stock returns (annualised)

Standard deviation of the daily stock returns times the ratio of the market value of equity to market value of total assets $* \sqrt{ } 250$

Firm specific risk from Bloomberg database 
2

3

4

5

6

7

8

9

10

11

12

13

14

15

16

17

18

19

20

21

22

23

24

25

26

27

28

29

30

31

32

33

34

35

36

37

38

39

40

41

42

43

44

45

46

47

48

49

50

51

52

53

54

55

56

57

Control Variables

Leverage

Firm Size

Growth

Lagged Performance

IND

YEAR
Average total assets over average total common equity

The market capitalisation of the firm in billions measured as the total value of issued shares

Capital expenditures over sales

The lagged return on assets for the firm measured in millions

Indicator variable that takes the value 1 if observation belongs to a particular industry, 0 otherwise

Indicator variable that takes the value 1 if the observation is in a particular year, 0 otherwise. 
Figure 1: An agency theory model that links board variables and company performance

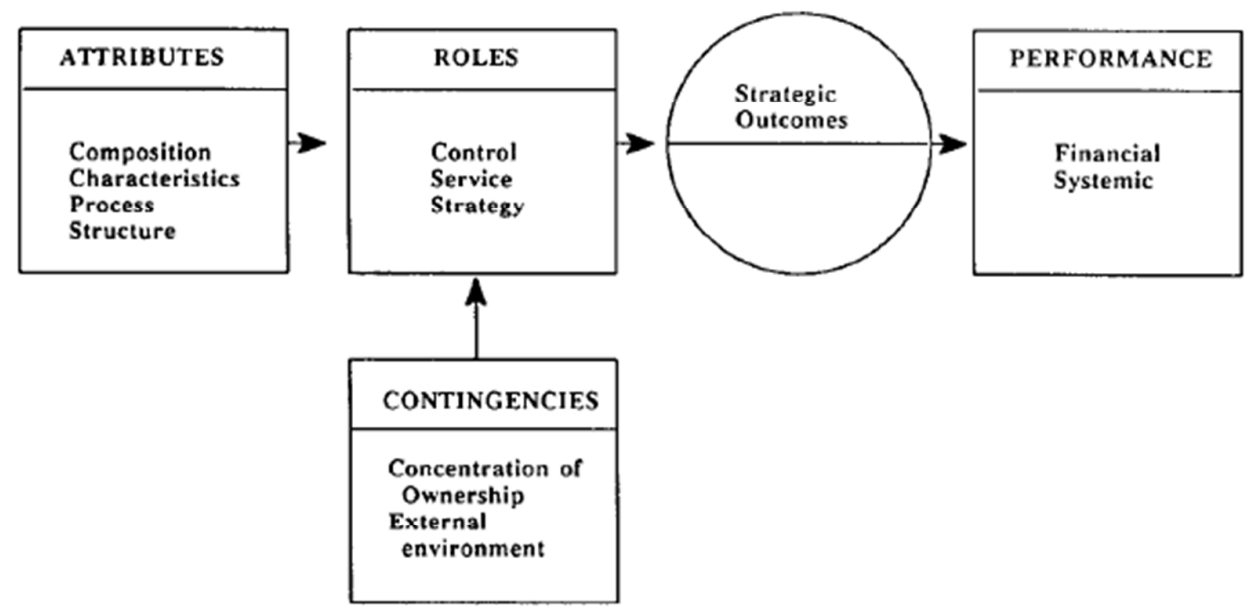

Source: Zahra and Pearce, 1989, p. 294 
Table 1: Industry distribution of sample by year

\begin{tabular}{llllllll}
\hline Industry sector & $\mathbf{2 0 0 5}$ & $\mathbf{2 0 0 6}$ & $\mathbf{2 0 0 7}$ & $\mathbf{2 0 0 8}$ & $\mathbf{2 0 0 9}$ & $\mathbf{2 0 1 0}$ & Total \\
\hline Oil and Gas & 17 & 18 & 16 & 19 & 18 & 16 & 104 \\
Basic materials & 14 & 16 & 15 & 19 & 21 & 21 & 106 \\
Industrials & 70 & 72 & 72 & 70 & 70 & 66 & 420 \\
Consumer goods & 33 & 35 & 31 & 31 & 31 & 29 & 190 \\
Healthcare & 9 & 8 & 8 & 8 & 8 & 8 & 49 \\
Consumer service & 65 & 68 & 69 & 70 & 72 & 69 & 413 \\
Telecommunications & 4 & 5 & 5 & 5 & 5 & 5 & 29 \\
Technology & 16 & 16 & 17 & 17 & 17 & 16 & 99 \\
\hline $\begin{array}{l}\text { Number of } \\
\text { Observations }\end{array}$ & 228 & 238 & 233 & 239 & 242 & 230 & 1,410 \\
\hline
\end{tabular}


TABLE 2: Descriptive statistics

$\mathrm{N}=1,410$

\begin{tabular}{|c|c|c|c|c|c|c|c|}
\hline & Mean & Q1 & Median & Q3 & Min & Max & $\mathrm{SD}$ \\
\hline \multicolumn{8}{|l|}{ Board Variables } \\
\hline Board Size & 8.95 & 7.00 & 9.00 & 10.00 & 5.00 & 19.00 & 2.35 \\
\hline Percentage of NEDs & 62.63 & 55.56 & 62.50 & 71.43 & 28.57 & 92.31 & 11.76 \\
\hline Percentage of women & 7.69 & 0.00 & 6.68 & 12.5 & 0.00 & 17.54 & 9.36 \\
\hline Powerful CEO & 0.18 & 0.00 & 0.00 & 0.00 & 0.00 & 1.00 & 0.39 \\
\hline Board Executive Ownership & 3.63 & 0.07 & 0.21 & 1.11 & 0.00 & 71.60 & 10.29 \\
\hline Block Ownership & 34.14 & 17.94 & 31.06 & 47.39 & 31.06 & 100 & 22.06 \\
\hline Board Age & 56 & 53.65 & 56.08 & 58.24 & 45.24 & 70.52 & 3.41 \\
\hline Board Tenure & 5.45 & 3.67 & 4.91 & 6.57 & 0.26 & 17.54 & 2.62 \\
\hline Board Attendance & 94.82 & 93.00 & 96.00 & 98.50 & 51.00 & 100.00 & 5.68 \\
\hline Frequency of Audit Meetings & 4.03 & 3.00 & 4.00 & 4.00 & 1.00 & 15.00 & 1.50 \\
\hline Governance Index & 4.34 & 3 & 4 & 6 & 0 & 9 & 1.75 \\
\hline \multicolumn{8}{|l|}{ Risk Measures } \\
\hline Total Risk & 0.40 & 0.26 & 0.35 & 0.47 & 0.14 & 1.62 & 0.20 \\
\hline Asset Return Risk & 0.39 & 0.26 & 0.34 & 0.47 & 0.13 & 1.54 & 0.19 \\
\hline Idiosyncratic Risk & -0.57 & -0.85 & -0.55 & -0.28 & -2.88 & 4.97 & 0.50 \\
\hline \multicolumn{8}{|l|}{ Control Variables } \\
\hline Leverage & 5.01 & 1.89 & 2.58 & 3.70 & -217.86 & $1,010.33$ & 39.69 \\
\hline Firm Size & 5.36 & 0.49 & 0.98 & 2.59 & 0.01 & 138.69 & 15.88 \\
\hline Growth & 11.40 & 1.82 & 3.45 & 7.29 & 0.02 & $1,555.21$ & 58.55 \\
\hline Lagged Performance & 7.57 & 3.38 & 6.56 & 10.64 & -175.74 & 175.92 & 12.26 \\
\hline
\end{tabular}

All variables are defined in the appendix. 


\section{TABLE 3: Correlation Coefficients}

\begin{tabular}{|c|c|c|c|c|c|c|c|c|c|c|c|c|c|c|}
\hline No & Variables & 1 & 2 & 3 & 4 & 5 & 6 & 7 & 8 & 9 & 10 & 11 & 12 & 13 \\
\hline 1 & Board size & 1 & & & & & & & & & & & & \\
\hline 2 & Proportion of NEDs & 0.12 & 1 & & & & & & & & & & & \\
\hline 3 & Presence of Women & 0.14 & 0.15 & 1 & & & & & & & & & & \\
\hline 4 & Powerful CEO & 0.02 & -0.42 & -0.12 & 1 & & & & & & & & & \\
\hline 5 & Board Ownership & -0.11 & -0.24 & -0.13 & 0.33 & 1 & & & & & & & & \\
\hline 6 & Block ownership & -0.13 & -0.01 & -0.09 & 0.07 & 0.02 & 1 & & & & & & & \\
\hline 7 & Board Age & 0.19 & 0.29 & -0.18 & -0.02 & -0.06 & -0.04 & 1 & & & & & & \\
\hline 8 & Board tenure & -0.01 & -0.25 & -0.09 & 0.19 & 0.01 & -0.02 & 0.20 & 1 & & & & & \\
\hline 9 & Board Attendance & -0.09 & -0.05 & -0.01 & -0.06 & 0.02 & -0.06 & 0.04 & 0.07 & 1 & & & & \\
\hline 10 & Frequency of Audit Meetings & 0.36 & 0.28 & 0.04 & -0.09 & -0.12 & -0.14 & 0.24 & -0.17 & -0.05 & 1 & & & \\
\hline 11 & Leverage & -0.00 & 0.02 & 0.03 & -0.04 & 0.01 & -0.05 & 0.01 & 0.04 & 0.03 & -0.01 & 1 & & \\
\hline 12 & Firm Size & 0.48 & 0.26 & 0.10 & -0.09 & -0.09 & -0.19 & 0.25 & -0.08 & -0.01 & 0.41 & -0.01 & 1 & \\
\hline 13 & Growth & -0.01 & -0.01 & -0.01 & 0.02 & 0.13 & 0.05 & -0.01 & -0.05 & 0.01 & -0.04 & -0.01 & -0.01 & 1 \\
\hline 14 & Lagged Performance & 0.00 & 0.01 & -0.03 & 0.01 & 0.07 & 0.05 & -0.04 & 0.02 & 0.02 & -0.01 & 0.01 & 0.06 & -0.05 \\
\hline
\end{tabular}

All correlation coefficients in bold are significant at the $10 \%$ level or below.

All variables are defined in the appendix. 
TABLE 4: Results from the regressions of Governance index with firm risk

The table presents coefficients (t-statistics) from model of the form:

$\operatorname{Ln}\left(\right.$ Risk $\left._{i t}\right)=\alpha_{0}+\alpha_{1}$ Governance Index $i t+\alpha_{2}$ Leverage $_{i t}+\alpha_{3}$ Firm Size $_{i t}+\alpha_{4}$ Growth $_{i t}+\alpha_{4}$

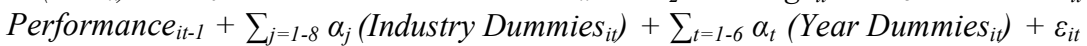

The regression is estimated using Generalized Least Square - Random effects methodology.

\begin{tabular}{|c|c|c|c|c|}
\hline Independent Variables & $\begin{array}{l}\text { Predicted } \\
\text { sign }\end{array}$ & $\begin{array}{l}\text { Total } \\
\text { Risk }\end{array}$ & $\begin{array}{l}\text { Asset } \\
\text { Return } \\
\text { Risk } \\
\end{array}$ & $\begin{array}{l}\text { Idiosyncratic } \\
\text { Risk }\end{array}$ \\
\hline Governance Index & - & $\begin{array}{l}-0.020 \\
(-3.79)^{* * *}\end{array}$ & $\begin{array}{l}-0.019 \\
(-3.72)^{* * *}\end{array}$ & $\begin{array}{l}-0.037 \\
(-4.30)^{* * *}\end{array}$ \\
\hline Leverage & - & $\begin{array}{l}0.000 \\
(-1.38)\end{array}$ & $\begin{array}{l}0.000 \\
(-1.44)\end{array}$ & $\begin{array}{l}0.000 \\
(-0.26)\end{array}$ \\
\hline Firm Size & - & $\begin{array}{l}0.000 \\
(-5.21)^{* * *}\end{array}$ & $\begin{array}{l}0.000 \\
(-5.35)^{* * *}\end{array}$ & $\begin{array}{l}0.56 \\
(-0.31)\end{array}$ \\
\hline Growth & + & $\begin{array}{l}0.000 \\
(0.62)\end{array}$ & $\begin{array}{l}0.001 \\
(0.71)\end{array}$ & $\begin{array}{l}0.000 \\
(1.11)\end{array}$ \\
\hline Lagged Performance & - & $\begin{array}{l}-0.001 \\
(-1.99)^{*}\end{array}$ & $\begin{array}{l}-0.001 \\
(-1.73) \dagger\end{array}$ & $\begin{array}{l}-0.000 \\
(-0.21)\end{array}$ \\
\hline Industry Dummies & & yes & yes & yes \\
\hline Year Dummies & & yes & yes & yes \\
\hline Constant & & $\begin{array}{l}-0.875 \\
(-16.63)^{* * *}\end{array}$ & $\begin{array}{l}-0.885 \\
(-7.62)^{* * *}\end{array}$ & $\begin{array}{l}2.066 \\
(-0.54)^{* * *}\end{array}$ \\
\hline No of observations & & 1,410 & 1,410 & 1,410 \\
\hline $\begin{array}{l}\text { Model fit: } \\
\text { Within } \mathrm{R}^{2}\end{array}$ & & 0.683 & 0.680 & 0.1062 \\
\hline Between $\mathrm{R}^{2}$ & & 0.485 & 0.504 & 0.3311 \\
\hline Overall $\mathrm{R}^{2}$ & & 0.584 & 0.588 & 0.1857 \\
\hline Wald $\mathrm{Chi}^{2}(17)$ & & $2,664.73$ & $2,649.12$ & 256.23 \\
\hline
\end{tabular}

$\dagger \mathrm{p}<.10, * \mathrm{p}<.05, * * \mathrm{p}<.01, * * * \mathrm{p}<.001$.

All variables are defined in the appendix. 
TABLE 5: Results from the regressions of Governance index using lagged independent variables with firm risk

The table presents coefficients (t-statistics) from model of the form:

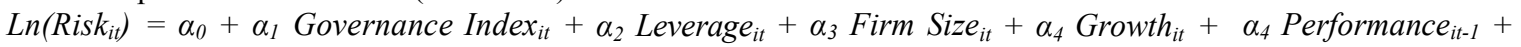
$\sum_{j=1-8} \alpha_{j}$ (Industry Dummies $\left.i t\right)+\sum_{t=1-6} \alpha_{t}($ Year Dummies $i t)+\varepsilon_{i t}$

The regression is estimated using Generalized Least Square - Random effects methodology.

The empirical model is estimated using lagged explanatory variables to correct for endogeneity.

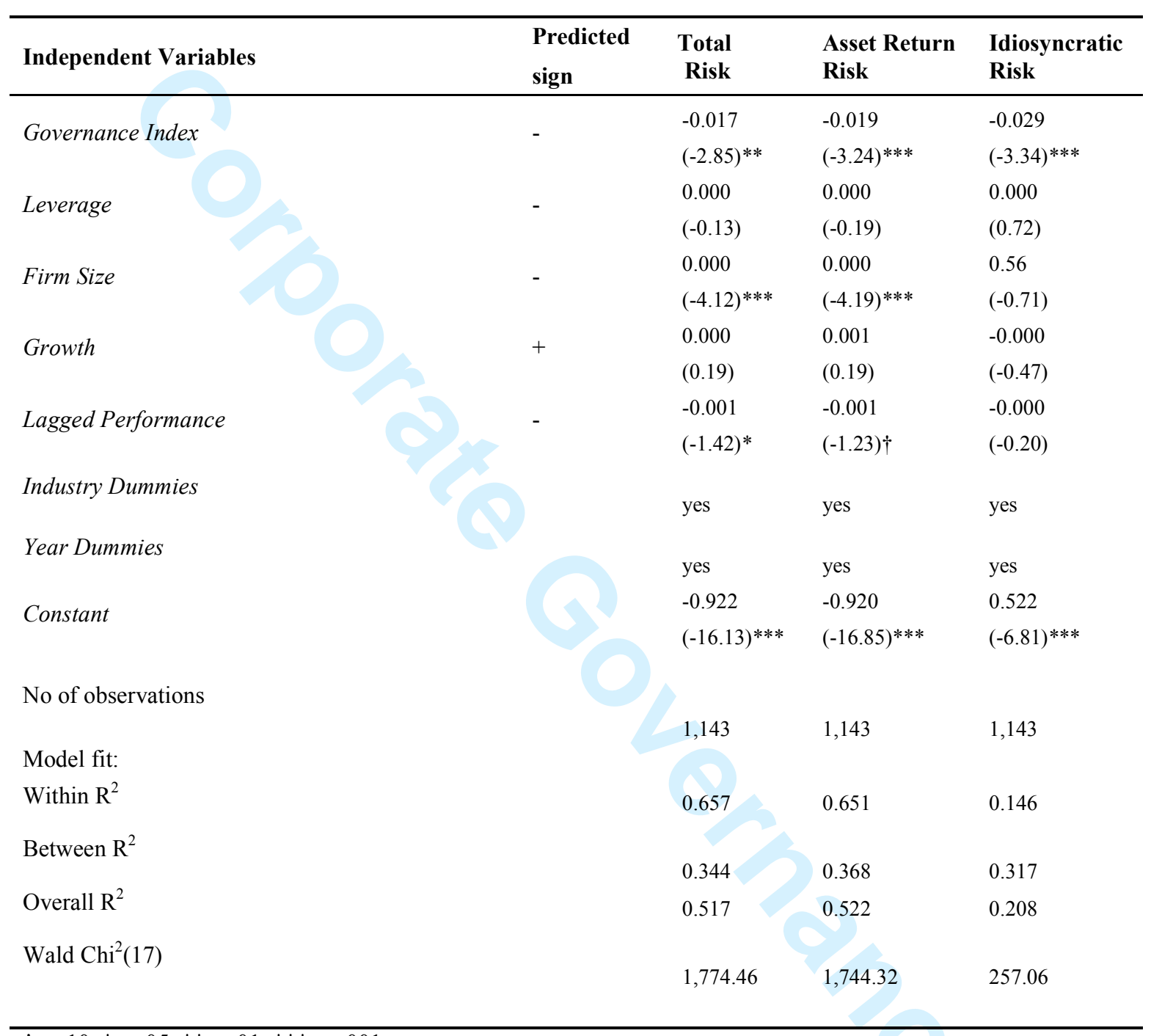

$\dagger \mathrm{p}<.10, * \mathrm{p}<.05, * * \mathrm{p}<.01, * * * \mathrm{p}<.001$.

All variables are defined in the appendix. 
TABLE 6: Results from the regressions of Governance index with firm risk Instrumental variables

The table presents coefficients (t-statistics) from model of the form:

Ln $\left(\right.$ Risk $\left._{i t}\right)=\alpha_{0}+\alpha_{1}$ Governance Index $_{i t}+\alpha_{2}$ Leverage $_{i t}+\alpha_{3}$ Firm Size $_{i t}+\alpha_{4}$ Growth $_{i t}+\alpha_{4}$ Performance $_{i t-1}+$ $\sum_{j=1-8} \alpha_{j}\left(\right.$ Industry Dummies $\left._{i t}\right)+\sum_{t=1-6} \alpha_{t}\left(\right.$ Year Dummies Dut $_{i t}+\varepsilon_{i t}$

The regression is estimated using Generalized Least Square - Random effects methodology.

Instrumental variables using xtivreg in STATA was used to estimate the model above using the board attributes as the instruments.

\begin{tabular}{|c|c|c|c|c|}
\hline Independent Variables & $\begin{array}{l}\text { Predicted } \\
\text { sign }\end{array}$ & $\begin{array}{l}\text { Total } \\
\text { Risk }\end{array}$ & $\begin{array}{l}\text { Asset } \\
\text { Return } \\
\text { Risk } \\
\end{array}$ & $\begin{array}{l}\text { Idiosyncratic } \\
\text { Risk }\end{array}$ \\
\hline Governance Index & - & $\begin{array}{l}-0.020 \\
(-3.67)^{* * *}\end{array}$ & $\begin{array}{l}-0.019 \\
(-3.59)^{* * *}\end{array}$ & $\begin{array}{l}-0.036 \\
(-4.08)^{* * *}\end{array}$ \\
\hline Leverage & - & $\begin{array}{l}0.000 \\
(-1.44)\end{array}$ & $\begin{array}{l}0.000 \\
(-1.50)\end{array}$ & $\begin{array}{l}0.000 \\
(-0.33)\end{array}$ \\
\hline Firm Size & - & $\begin{array}{l}0.000 \\
(-4.96)^{* * *}\end{array}$ & $\begin{array}{l}0.000 \\
(-5.11)^{* * *}\end{array}$ & $\begin{array}{l}0.000 \\
(-0.44)\end{array}$ \\
\hline Growth & + & $\begin{array}{l}0.000 \\
(0.49)\end{array}$ & $\begin{array}{l}0.001 \\
(0.61)\end{array}$ & $\begin{array}{l}0.000 \\
(0.07)\end{array}$ \\
\hline Lagged Performance & - & $\begin{array}{l}-0.001 \\
(-1.96)^{*}\end{array}$ & $\begin{array}{l}-0.001 \\
(-1.72) \dagger\end{array}$ & $\begin{array}{l}-0.000 \\
(-0.09)\end{array}$ \\
\hline Industry Dummies & & yes & yes & yes \\
\hline Year Dummies & & yes & yes & yes \\
\hline Constant & & $\begin{array}{l}-0.876 \\
(-16.02)^{* * *}\end{array}$ & $\begin{array}{l}-0.887 \\
(- \\
16.80)^{* * *}\end{array}$ & $\begin{array}{l}2.066 \\
(-0.53)^{* * *}\end{array}$ \\
\hline No of observations & & 1,358 & 1,358 & 1,358 \\
\hline $\begin{array}{l}\text { Model fit: } \\
\text { Within } \mathrm{R}^{2}\end{array}$ & & 0.677 & 0.674 & 0.105 \\
\hline Between $\mathrm{R}^{2}$ & & 0.488 & 0.496 & 0.298 \\
\hline Overall $\mathrm{R}^{2}$ & & 0.579 & 0.582 & 0.184 \\
\hline Wald $\mathrm{Chi}^{2}(17)$ & & $2,505.18$ & $2,485.93$ & 237.95 \\
\hline
\end{tabular}

$\dagger \mathrm{p}<.10, * \mathrm{p}<.05, * * \mathrm{p}<.01, * * * \mathrm{p}<.001$.

All variables are defined in the appendix. 